\title{
Holoprosencephaly-polydactyly ('pseudotrisomy 13') syndrome: a syndrome with features of hydrolethalus and Smith-Lemli-Opitz syndromes. A collaborative multicentre study
}

\author{
A Verloes, S Aymé, D Gambarelli, M Gonzales, M Le Merrer, N Mulliez, N Philip, J Roume
}

\begin{abstract}
A syndrome of holoprosencephaly and postaxial polydactyly, associated with hydrocephalus, heart defect, adrenal hypoplasia, and other visceral malformations, has been observed in five unrelated children with normal chromosomes. Clinical overlap with lethal acrodysgenital dwarfism (SmithLemli-Opitz syndrome type II) and hydrolethalus syndrome is discussed. Recessive inheritance seems likely.
\end{abstract}

Holoprosencephaly and polydactyly are the hallmarks of trisomy 13 and allow a consistent diagnosis in most instances. However, isolated cases suggested the existence of a non-chromosomal syndrome which mimics, at first glance, the external anomalies of trisomy 13. Five new observations allow us to delineate more accurately this new multiple congenital anomaly syndrome.

Centre for Human Genetics, Liège University, Pathologie B23, CHU Sart-Tilman, B-4000 Liège, Belgium.

A Verloes

Centre of Medical Genetics and INSERM U242, Hôpital de la Timone, Marseille, France.

S Aymé, N Philip

Department of Pathology, Hôpital de la Timone, Marseille, France.

D Gambarelli

Department of Embryology and Fetal Pathology, Hôpital St Antoine, Paris, France.

M Gonzales, N Mulliez, J Roume

Clinique de Génétique Médicale and INSERM U12, Hôpital Necker-Enfants Malades, Paris, France.

M Le Merrer

Correspondence to Dr Verloes.

Received for publication 26 April 1990.

Revised version accepted for publication 27 September 1990.

\section{Case reports}

CASE 1

This stillborn girl was delivered at 34 weeks of gestation. Hydramnios was reported at $51 \frac{1}{2}$ months. Birth weight was $1980 \mathrm{~g}$ (10th centile), length $43 \mathrm{~cm}$ (50th centile), and OFC $34 \mathrm{~cm}$ (>90th centile). Cyclopia with proboscis, microstomia, thick dysplastic ears, and postaxial polydactyly of the upper limbs were noted. There were no visceral malformations, except for atrial septal defect of the ostium secundum type. Microscopic examination of several organs, including pancreas and kidneys, showed them to be normal. The fetal zone of both adrenals was hypo/ aplastic. The brain was a very small holosphere surrounded by very enlarged subarachnoid spaces. The hypophysis was absent. Chromosomal analysis was normal, 46,XX. The parents were Brazilian; the father was 31 and the mother 30 . No family data were available.

CASE 2

This hydropic female fetus died in utero at 26 weeks by dates. She weighed $920 \mathrm{~g}$ and was $35 \mathrm{~cm}$ long. OFC was not recorded (vault dislocation). Premaxillary agenesis, cleft palate, and bilateral postaxial polydactyly of the upper limbs were present. Visceral malformations included cardiomegaly, D transposition of the great vessels, a left sided vena cava flowing into the left atrium, and a large persistent ductus arteriosus. The oesophagus was narrowed at the level of the carina. The gut was malrotated. The kidneys and liver were normal but the adrenals were absent. Tissue lysis prevented accurate examination of the brain. Karyotype was normal, 46,XX. The father was 27 and the mother 22 years old. They were not consanguineous and their karyotypes were normal. The mother had had two previous spontaneous abortions at 10 and 12 weeks, respectively (not examined).

CASE 3

This male fetus was born at 33 weeks of gestation after transvaginal decompression of hydrocephalus. 


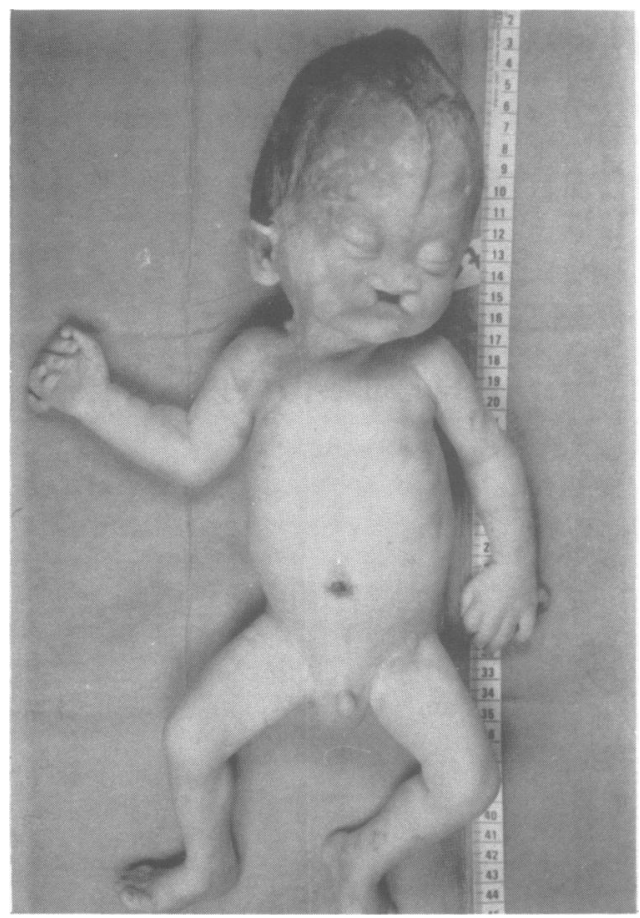

Figure 1 Patient 3.

Weight was $1760 \mathrm{~g}$, length $44 \mathrm{~cm}$, and OFC $34 \mathrm{~cm}$. Premaxillary hypoplasia with bilateral labiopalatine clefts, microphthalmia, bilateral upper limb postaxial polydactyly, and slight penile hypoplasia were observed (fig 1). Necropsy showed an endocardial cushion defect, a left vena cava, abnormal pulmonary segmentation, aplasia of the gall bladder, and testicular hypoplasia, and $x$ rays showed hemivertebrae at the S2 level. The brain weighed $150 \mathrm{~g}$. The olfactory tracts were absent. Holoprosencephaly was of the semilobar type and hypophysis was present. Microscopic examination showed that the kidneys, liver, adrenals, thymus, thyroid, lungs, pancreas, spleen, and testes were normal. The karyotype was normal, $46, \mathrm{XY}$. He was the first child of non-consanguineous parents and the family history was unremarkable.

\section{CASE 4}

Hydrocephalus and holoprosencephaly were suspected on ultrasound in this fetus. An amniocentesis was performed despite oligohydramnios. The fetal karyotype was 46,XY. Acetylcholinesterase electrophoresis and $\alpha$ fetoprotein level were normal. However, owing to the severity of the hydrocephalus, a termination of pregnancy was performed at 20 weeks. The fetus weighed $300 \mathrm{~g}$. External anomalies included a median cleft lip and complete cleft palate, hypertelorism, a short neck (fig 2), bilateral postaxial polydactyly of both upper and lower limbs, and club feet (fig 3). Necropsy showed incomplete segmentation of the lungs, a ventricular septal defect, and bilateral hypoplastic kidneys. The extremely small brain was explained by alobar holoprosencephaly (fig $4 \mathrm{~b}, \mathrm{c}, \mathrm{d})$. The suspected hydrocephalus was in fact an almost empty skull (fig 4a). Gyration was grossly abnormal. The cerebellum and the eyes were normal. This fetus was the product of the first pregnancy of a young gypsy couple (mother aged 20) with a high degree of consanguinity (probable brother-sister union). With a different partner, the mother had had another pregnancy two years earlier which ended in a stillborn male which was not examined.

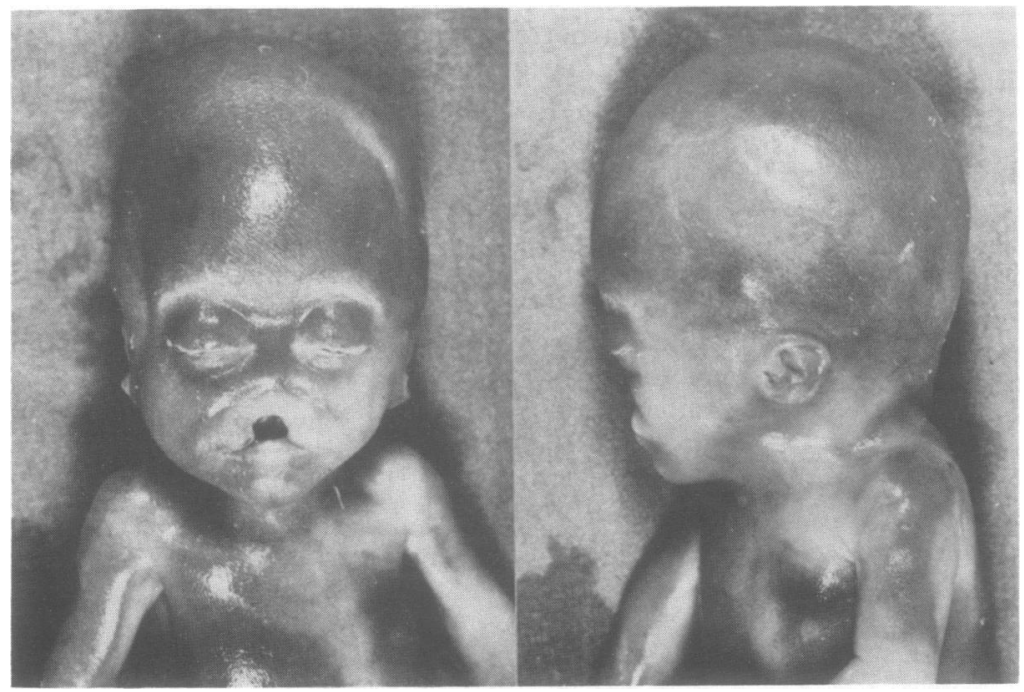

Figure 2 Patient 4: facial features. 


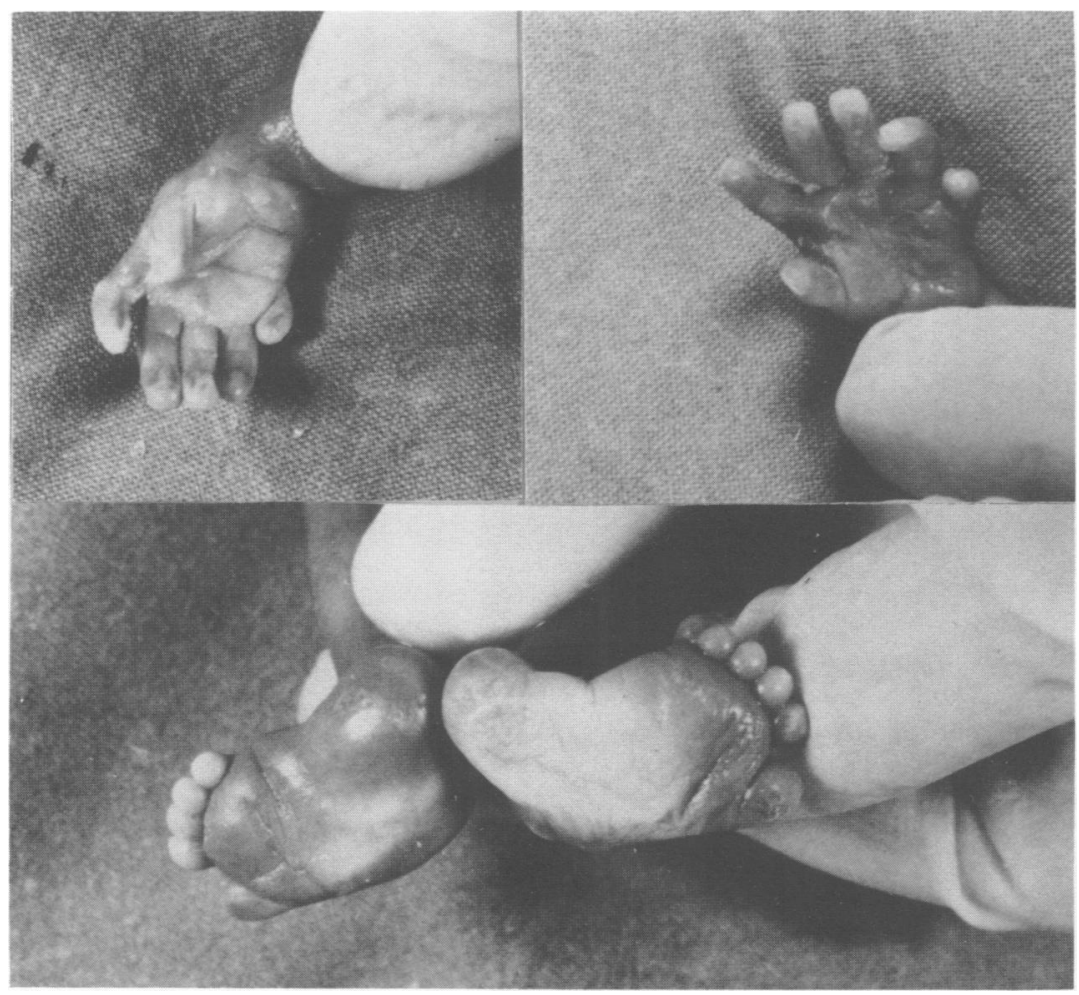

Figure 3 Patient 4: acral anomalies.

\section{CASE 5}

This stillborn male was born at 31 weeks of gestation. He was the product of the third pregnancy of an unrelated young couple who already had a normal boy and who had had a spontaneous abortion. After this stillbirth, they had two further pregnancies, carefully monitored by ultrasound, which resulted in the birth of two normal boys.

During the pregnancy of this case, the mother had salpingitis treated by tetracyclines and prednisone $(60$ $\mathrm{mg} /$ day) from the third to the tenth week of gestation. Polyhydramnios developed at the beginning of the sixth month, which necessitated several evacuations. Because of a suspicion of hydrocephalus on ultrasound, a fetal karyotype was performed at 28 weeks on amniotic cells, which was normal, 46,XY. The fetus died spontaneously at 31 weeks and was immediately evacuated. It weighed $1800 \mathrm{~g}$ (50th centile) and showed an absence of ocular globes, a single nostril, bilateral postaxial polydactyly, and hypoplastic male external genitalia. Necropsy showed the presence of a large ventricular septal defect and agenesis of the adrenal glands. The diagnosis of hydrolethalus syndrome was proposed at that time (1984).

\section{Discussion}

The clinical spectrum of defects seen in these five cases is consistent: holoprosencephaly sequence (with its secondary facial consequences), visceral malformations (mostly heart defects), and polydactyly. It suggests at first glance trisomy 13 .

\section{REVIEW OF PUBLISHED REPORTS}

Eight previous reports have described the same syndrome. In 1986, Lieber et al briefly reported a stillborn infant with holoprosencephaly, heart defect, male pseudohermaphroditism, and polydactyly. Smith-Lemli-Opitz (SLO) syndrome was the suggested diagnosis. In a paper on the possible identity of the SLO and the hypothalamic hamartoblastoma syndrome (HHS), Donnai et $a l^{2}$ reported two fetuses with holoprosencephaly, polydactyly, and anal stenosis, one of which had male pseudohermaphroditism. In 1987, Young and Madders ${ }^{3}$ described a stillborn infant with holoprosencephaly, microphthalmia, hydrocephalus, polydactyly, and a heart defect as a 'new syndrome'. This paper prompted several comments: Moerman and Fryns ${ }^{4}$ reported a 


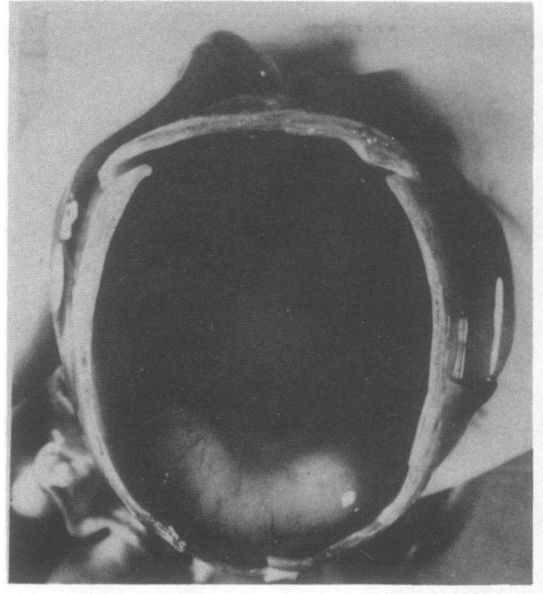

(a)

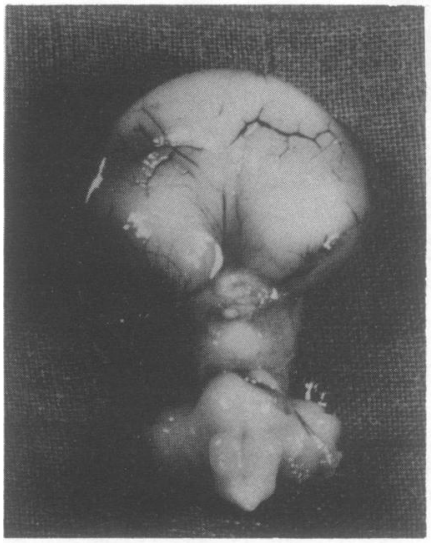

(c)
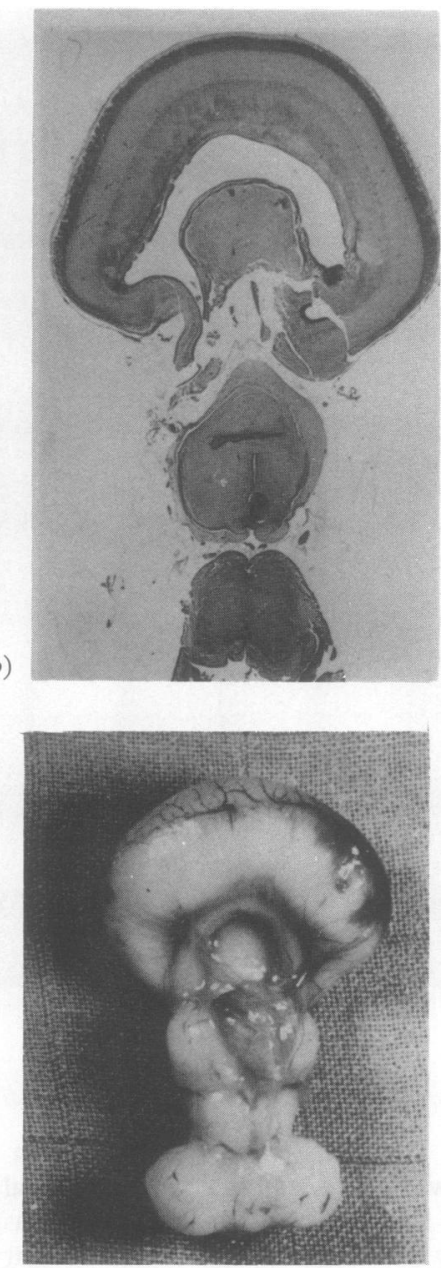

(d)
Figure 4 Brain pathology (courtesy of DrD Gambarelli). (a) Empty skull with very small brain. (b) Frontal section. (c, d) Macroscopic aspect. stillborn female with holoprosencephaly, hydrocephalus, microphthalmia, polydactyly, and adrenal and thyroid hypoplasia, and stated that she had the same syndrome as that described by Young and Madders $^{3}$ and not hydrolethalus syndrome (HLS). André $e t a l^{5}$ described a boy with cebocephaly, polydactyly, umbilical hernia, hypospadias with micropenis, thyroid, adrenal, and testicular hypoplasia, and ASD. These authors favoured the diagnosis of HLS. Atkin et at briefly described two 46,XY sibs with ambiguous genitalia and polydactyly: the first one had microcephaly, hypotelorism, and an imperforate anus; the second one had cyclopia, a heart defect, and ambiguous genitalia. The authors excluded SLO. Hewitt et $a l^{7}$ described an 18 week old aborted male fetus with holoprosencephaly, hydrocephalus, polydactyly, and an 'asymmetrical' heart. They suggested that their fetus had the same disorder as the one reported by Young and Madders, and coined the term 'pseudotrisomy 13'. Bachman $e t a l^{8}$ reported on two aborted sibs with holoprosencephaly, hydrocephalus, and polydactyly. They suggested that these fetuses (as well as that of Young and Madders ${ }^{3}$ and other cases) had HLS. The main clinical features of 16 cases are summarised in the table. We excluded the case of Shiota and Tanimura, ${ }^{9}$ who described a 6 week old male embryo with holoprosencephaly, tetramelic polydactyly, and VSD, as chromosomal analysis was not reported.

\section{RATIONALE FOR CLINICAL DELINEATION}

We have considered the alternative diagnostic options described in published reports. 
Clinical features in 11 published and five personal cases of holoprosencephaly-polydactyly syndrome.

\begin{tabular}{|c|c|c|c|c|c|c|c|c|c|c|c|c|c|c|c|c|c|}
\hline & \multicolumn{16}{|c|}{ Reference and (case no) } & \multirow{3}{*}{$\begin{array}{l}\text { Total } \\
16\end{array}$} \\
\hline & \multirow{2}{*}{$\begin{array}{c}1 \\
(1)\end{array}$} & \multirow{2}{*}{$\begin{array}{c}2 \\
(1)\end{array}$} & \multicolumn{2}{|c|}{3} & \multirow{2}{*}{$\begin{array}{c}4 \\
(1)\end{array}$} & \multirow{2}{*}{$\begin{array}{c}5 \\
(1)\end{array}$} & \multicolumn{2}{|c|}{6} & \multirow{2}{*}{$\begin{array}{c}7 \\
(1)\end{array}$} & \multicolumn{2}{|c|}{8} & \multirow[b]{2}{*}{ (1) } & \multicolumn{3}{|c|}{ This report } & \multirow[b]{2}{*}{$(5)$} & \\
\hline & & & $\overline{(1)}$ & $(2)$ & & & $\overline{(1)}$ & $\overline{(2)}$ & & $\overline{(1)}$ & $\overline{(2)}$ & & (2) & (3) & (4) & & \\
\hline Hydramnios & $?$ & $?$ & - & - & - & - & - & - & - & - & - & + & - & - & - & + & 2 \\
\hline Hydrops fetalis & ? & - & - & - & - & - & - & - & - & - & - & - & + & - & - & - & 1 \\
\hline Parental consanguinity & j & - & - & - & - & - & - & - & - & + & + & $?$ & - & $?$ & + & - & \\
\hline Age (father) & $?$ & 30 & $?$ & $?$ & 57 & 31 & $?$ & & 45 & $?$ & & 31 & 25 & $?$ & $?$ & 26 & Mean: 35 \\
\hline Age (mother) & ? & 25 & ? & ? & 34 & 31 & 30 & & 28 & 29 & & 30 & 22 & ? & 20 & 23 & Mean: $27 \cdot 2$ \\
\hline Hydrocephalus & ? & + & - & - & + & + & - & $?$ & + & + & + & $?$ & + & + & + & + & 10 \\
\hline Holoprosencephaly & + & PA & $\mathrm{CE}$ & PA & ET & CE & HY & CY & PA & CE & + & $\mathrm{CY}$ & PA & PA & PA & CE & 16 \\
\hline Cerebellar hypoplasia & $?$ & $?$ & ? & ? & + & $?$ & ? & $?$ & $?$ & + & $?$ & $?$ & $?$ & $?$ & - & $?$ & 2 \\
\hline Antehypophysis aplasia & ? & ? & ? & ? & + & ? & ? & ? & ? & $?$ & ? & + & ? & ? & $?$ & ? & 2 \\
\hline $\begin{array}{l}\text { Eye anomaly } \\
\text { (excluding microphthalmia) }\end{array}$ & , & 2 & 2 & CA & RD & AN & - & $\lambda$ & 2 & 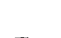 & - & 2 & & 2 & - & AN & 4 \\
\hline $\begin{array}{l}\text { (excluding } n \\
\text { Heart defect }\end{array}$ & $\stackrel{?}{+}$ & $\stackrel{?}{2}$ & $\stackrel{?}{-}$ & CA & KD & ${ }_{2}^{\text {AN }}$ & - & 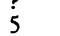 & $\stackrel{?}{7}$ & $\overline{-}$ & ? & $\stackrel{?}{2}$ & i, 6,8 & $\stackrel{?}{2,4}$ & $\overline{3}$ & $\begin{array}{l}\text { AN } \\
3\end{array}$ & $\begin{array}{r}4 \\
10\end{array}$ \\
\hline Lung malsegmentation & $?$ & - & $?$ & + & - & - & $?$ & - & - & - & $?$ & - & - & + & + & - & 3 \\
\hline Gut malrotation & ? & - & - & + & - & - & ? & $?$ & - & - & j & - & + & - & - & - & 2 \\
\hline adder aplasia & j & - & $?$ & ? & - & - & ? & ? & - & $?$ & ? & - & - & + & - & - & 1 \\
\hline Umbilical hernia & ? & - & - & - & - & + & - & - & - & + & ? & - & + & - & - & - & 3 \\
\hline Kidney hypoplasia & ? & - & + & + & - & $?$ & $?$ & $?$ & - & - & ? & - & - & - & + & - & 3 \\
\hline Imperforate anus & - & - & + & + & - & - & + & + & - & - & - & - & - & - & - & - & 4 \\
\hline Adrenal hypoplasia & ? & ? & $?$ & + & + & + & $?$ & $?$ & + & ? & $?$ & + & + & - & ? & + & 7 \\
\hline Thyroid hypoplasia & 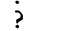 & ? & ? & $?$ & + & + & ? & ? & $?$ & ? & & $?$ & ? & ? & ? & - & 2 \\
\hline Karyotype & $\mathrm{XY}$ & $\mathrm{XY}$ & $\mathrm{XY}$ & $\mathrm{xx}$ & $\mathrm{XX}$ & $\mathrm{XY}$ & $\mathrm{XY}$ & $\mathrm{XY}$ & $\mathrm{XY}$ & $\mathrm{XY}$ & (XY?) & $\mathrm{xx}$ & $\mathrm{xx}$ & $\mathrm{XY}$ & $\mathrm{XY}$ & $\mathrm{XY}$ & Sex ratio: \\
\hline Ambiguous male genitalia & + & - & + & & & - & + & + & - & - & - & & & - & - & - & $4 / 12$ males \\
\hline Penile h & + & + & + & & & + & + & + & $?$ & $?$ & $?$ & & & + & - & + & 8 \\
\hline Hypospacias & + & - & + & & & + & + & + & - & - & ? & & & + & - & - & 6 \\
\hline Testicular hypoplasia & $?$ & - & $?$ & & & + & $?$ & $?$ & $?$ & $?$ & $?$ & & & + & - & + & 3 \\
\hline UL postaxial polydactyly & + & + & + & + & + & - & + & - & + & + & + & + & + & + & + & + & 14 \\
\hline LL postaxial polydactyly & - & - & + & - & - & + & - & + & + & + & + & - & - & - & + & + & 8 \\
\hline Club feet & ? & + & + & + & - & - & + & - & - & - & - & - & - & - & + & - & 5 \\
\hline Sacral anomalies & + & $?$ & $?$ & $?$ & $?$ & ? & $?$ & ? & $?$ & $?$ & $?$ & ? & - & + & $?$ & - & 2 \\
\hline Miscarriage/stillborn & ? & - & - & - & - & $4 / 0$ & - & & - & - & & - & $2 / 0$ & - & $0 / 1$ & $1 / 0$ & \\
\hline
\end{tabular}

?=Not mentioned. $\mathrm{CA}=$ cataracts. $\mathrm{RD}=$ retinal dysplasia. $\mathrm{AN}=$ anophthalmia. $\mathrm{PA}=$ premaxillary agenesis. $\mathrm{CY}=$ cyclopia. $\mathrm{ET}=$ ethmocephaly. $\mathrm{CE}=$ cebocephaly. $\mathrm{HY}=$ hypertelorism. $1=\mathrm{PDA} .2=\mathrm{ASD} .3=\mathrm{VSD} .4=$ endocardial cushion defect. $5=$ single ventricle. $6=\mathrm{D}$ transposition. $7=$ 'asymmetrical' heart. $8=$ abnormal venous return.

Lethal acrodysgenital dwarfism (LAD) or Smith-LemliOpitz type II

Although the clinical heterogeneity of Smith-LemliOpitz (SLO) syndrome was suspected for a long time, its severe form was only definitely delineated in 1987 by Curry $e t a l^{10}$ and in 1988 by Le Merrer et al. ${ }^{11}$ Over 50 cases were collected, most of them already published as 'common' SLO, and some with other diagnoses. This autosomal recessive syndrome shows specific facial dysmorphism, severe IUGR, multiple visceral malformations, and sexual ambiguity or sex reversal. Agenesis of the corpus callosum is common but neither holoprosencephaly nor imperforate anus has been reported. Its genetic independence from 'classical' SLO (type I) is still in dispute. Donnai et $a l^{2}$ established this diagnosis for their two cases. In abstract 1 of Lieber et al, ${ }^{1}$ many features were consistent with the diagnosis of LAD, although IUGR was absent. SLO and LAD are primarily dysmorphic syndromes, but holoprosencephaly blurs the typical facial anomalies. Atkin ${ }^{6}$ excluded the diagnosis of LAD for the less affected child of his report, who had only minor facial involvement, but no illustrations were published. Micrognathia was only quoted in case 1 of Donnai et al. ${ }^{2}$ Nevertheless, four out of 11 male cases showed the typical 'sex reversal', two of whom had $2 / 3$ cutaneous syndactyly of the toes.

\section{Hydrolethalus syndrome}

This is a lethal, recessively inherited syndrome reported almost exclusively from Finland. ${ }^{12}{ }^{13}$ It includes midbrain anomalies (midline cleft with agenesis of the corpus callosum and ventriculosubarachnoid fistula) with severe external hydrocephalus, micropolygyria, key hole shaped foramen magnum, deep and wide set eyes, facial clefts, micrognathia, atrioventricular defects, postaxial polydactyly of the upper limbs, 'pathognomonic' preaxial polydactyly (hallux duplex) of the lower limbs (sometimes associated with postaxial polydactyly), club feet, and laryngotracheopulmonary malformations. Polyhydramnios is also a feature. In more than 50 cases of HLS, no holoprosencephaly has been reported ${ }^{13}$ although olfactory bulbs were absent in one case. ${ }^{12}$ Taking each case separately, the phenotype of our patients seems closely related to HLS, but, if we tabulate the features of the 16 cases with holoprosencephaly, the pattern of defects is different. Polydactyly of the feet, when present, is always 
postaxial, and never associated with hallux duplex (case 1 of Bachman et $a l^{8}$ had "splayed, broad hallux"), and hydramnios has been noted only twice. Moreover, sexual ambiguity has not been observed in HLS, and anterior cleft of the foramen magnum has not been reported among the children with holoprosencephaly.

\section{Acrocallosal syndrome 1415}

This is defined as the association of hypertelorism, absent corpus callosum, postaxial polydactyly of the hands/feet, and inconstant hallux duplex. It could represent an allelic, attenuated form of HLS. ${ }^{16}{ }^{17}$ No holoprosencephaly has ever been reported.

\section{Hypothalamic hamartoblastoma syndrome}

About 24 children have been reported with hypothalamic hamartoblastoma, antehypophyseal insufficiency, multiple visceral anomalies, and postaxial polydactyly. In three cases, holoprosencephaly was present. ${ }^{18-20}$ Diagnosis is straightforward at necropsy, but can easily be missed on CT scanning. AnyaneYeboa $e t a l^{21}$ described a child with holoprosencephaly and hypothalamic hamartoma as having HLS, but it was more likely to have been affected by hypothalamic hamartoblastoma syndrome. This diagnosis could not be ruled out in our patient 2 .

\section{Varadi-Papp syndrome (orofaciodigital syndrome type VI)}

This syndrome was reported in an inbred Hungarian gypsy family. ${ }^{22}$ Features included hallux duplex, polydactyly, cleft lip/palate, heart defect, and mental retardation. Arhinencephaly was reported in some cases. A combination of hypoplasia of the vermis, lingual tumours, and gingival frenula is pathognomonic.

\section{Grote syndrome}

This unique combination of holoprosencephaly, tetramelic octodactyly, heart defect, bilateral tibial agenesis, and multivisceral malformations was reported in a single family. ${ }^{23}$

\section{Trisomy 13}

This chromosomal anomaly should be considered, although it is easy to rule out. The common statement ${ }^{24}$ that trisomy 13 is likely if holoprosencephaly is associated with many extracephalic manifestations (while chromosomes are more often normal if holoprosencephaly occurs as an isolated anomaly) remains true. Nevertheless, diagnosis of trisomy 13 is possible in a stillborn infant with holoprosencephaly and polydactyly for which chromosome analysis failed (or was not done). Misleading genetic counselling and inappropriate prenatal diagnosis could ensue. Microdysplasia of the pancreas is considered to be the most specific histopathological change in trisomy $13 .{ }^{25}$ Systematic pancreatic sampling could be an advisable policy when the karyotype is not known at the time of necropsy. Ectopic splenic tissue has not been observed.

Most of the malformations in these syndromes are explained by a very early disturbance of organogenesis which begins about the fifth week (Streeter's stages XIV to XVI). One may hypothesise that at least part of the malformation complex observed in LAD, HLS, trisomy 13, and in our patients could be the result of a specific, primitive, genetically determined event that alters the development of the brain and perhaps of other structures (such as limb bud differentiation). This disturbance could induce secondary developmental field defects by either mechanical constraint, specific or non-specific biochemical deregulation of induction and cellular interactions, or by desynchronisation of parallel sequential events. Most of the malformations observed in the newborn could then be considered as sequence(s), and the homology between several syndromes would only reflect a similarity in chronology and topography of the primitive event. Then, they would lose most of their significance for nosology and differential diagnosis. Hypothalamic hamartoblastoma syndrome (HHS) gives some support to this theory: this multiple malformation syndrome is associated with a focal tumour of very early onset. Phenotypic expression varies from almost normal children to holoprosencephaly, polydactyly, and multivisceral malformations. Of even greater interest are the observations of some features resembling HHS associated with apparently non-tumoural grey matter ectopia ${ }^{19}$ or subarachnoid cysts ${ }^{26}$ localised in the same area.

Based on these considerations, and in the ignorance of the true pathophysiology of these syndromes of multiple congenital anomalies, we suggest (following the opinion of Cohen ${ }^{27}$ ) that holoprosencephaly could be specific enough to justify the delineation of a provisionally 'new' syndrome.

Accurate incidence is impossible to discover. No other convincing records were found in our larger series of fetal/neonatal necropsies which included 5000 records from St Antoine Hospital, Paris, 2100 from Marseille, and 2000 from Liège+Loverval. Most surveys on holoprosencephaly were undertaken before the cytogenetic era and no compatible cases are quoted in more recent reviews. ${ }^{27-34}$ Underdevelopment of the adrenals or thyroid or both was recorded in most cases, which is likely to be explained by some degree of hypopituitarism. This should be investigated in further reports. The sex ratio is 12:4. 


\section{INHERITANCE AND GENETIC COUNSELLING}

Most cases have been sporadic. Two published cases and the very close consanguinity of our case 4 are strong arguments for an autosomal recessive mode of inheritance. Nevertheless, strikingly high parental ages in several isolated cases could be an argument for de novo dominant mutation. Submicroscopic chromosomal duplication or rearrangement in the region extending between $13 \mathrm{q} 31$ and $13 \mathrm{q} 34$ is an alternative hypothesis. It should be tested in further cases by high resolution banding and appropriate DNA probes. As long as this problem is not resolved, genetic counselling must be carried out very cautiously.

We do not recommend the use of 'pseudotrisomy 13 syndrome' (suggested by Hewitt et $a l^{7}$ and Cohen ${ }^{27}$ ) to describe this syndrome. This is confusing for a cytogenetically normal syndrome, and the pathological findings are not identical. 'Holoprosencephalypolydactyly syndrome' appears to be a more neutral term, and summarises the two most salient clinical features.

1 Lieber E, Valdarama E, Chasalow F. Multiple malformation syndrome suggestive of Smith-Lemli-Opitz syndrome with holoprosencephaly in a 46,XY still-born infant. Am $\mathrm{F} \mathrm{Hum}$ Genet 1986;3\%(suppl):200A.

2 Donnai D, Burn J, Hughes H. Smith-Lemli-Opitz syndromes: do they include the Pallister-Hall syndrome? Am 7 Med Genet 1987;28:741-3.

3 Young ID, Madders DJ. Unknown syndrome: holoprosencephaly, congenital heart defects, and polydactyly. $\mathcal{F}$ Med Genet 1987;24: $714-6$.

4 Moerman P, Fryns JP. Holoprosencephaly and postaxial polydactyly: another observation. $f$ Med Genet 1988;25:501-4.

5 André SA, Cordier MP, Beaufrère AM, Guillaud M, Robert JM. Holoprosencéphalie, polydactylie, cardiopathie: nouveau syndrome ou nouveau cas d'hydroléthalus. I Genet Hum 1988;36:463-8.

6 Atkin JF. A new syndrome with cyclopia and trisomy 13 features. Am $\mathcal{F}$ Hum Genet 1988;43(suppl):143A.

7 Hewitt BG, Seller MJ, Bennet CP, Maxwell DM. Holoprosencephaly, polydactyly and normal chromosomes: pseudotrisomy 13? Clin Genet 1989;36:141-3.

8 Bachman H, Clark RD, Salahi W. Holoprosencephaly and polydactyly: a possible expression of the hydrolethalus syndrome. F Med Genet 1990;27:50-2.

9 Shiota K, Tanimura T. Holoprosencephaly, ventricular septal defect, and postaxial polydactyly in a human embryo. 7 Med Genet 1988;25:502-3.

10 Curry CL, Carey JC, Holland JS, et al. Smith-Lemli-Opitz syndrome-type II: multiple congenital anomalies with male pseudohermaphroditism and frequent early lethality. Am $\mathcal{f}$ Med Genet 1987;260:45-57.

11 Le Merrer M, Briard ML, Girard S, Mulliez N, Moraine C, Imbert MC. Lethal acrodysgenital dwarfism; a severe lethal condition resembling Smith-Lemli-Opitz syndrome. $f$ Med Genet 1988;25:88-95.
12 Salonen R, Herva $\mathbf{R}$, Norio $\mathbf{R}$. The hydrolethalus syndrome: delineation of a "new" lethal malformation syndrome based on 28 patients. Clin Genet 1981;19:321-30.

13 Salonen R, Herva R. Hydrolethalus syndrome. 7 Med Genet 1990;27:756-9.

14 Schinzel A, Schmid W. Hallux duplication, postaxial polydactyly, absence of the corpus callosum, severe mental retardation and additional anomalies in two unrelated patients: a new syndrome. Am 7 Med Genet 1980;6:241-9.

15 Philip N, Apicella N, Lassman I, Aymé S, Mattei JF, Giraud F. The acrocallosal syndrome. Eur $\mathcal{F}$ Pediatr 1988;147:206-8.

16 Schinzel A, Kaufmann U. The acrocallosal syndrome in sisters. Clin Genet 1986;30:399-405.

17 Aughton DJ, Cassidy SB. Hydrolethalus syndrome: report of an apparent mild case, literature review, and differential diagnosis. Am $\mathcal{F}$ Med Genet 1984;27:935-42.

18 Hall JG, Pallister PD, Clarren SK, et al. Congenital hypothalamic hamartoblastoma, hypopituitarism, imperforate anus, and postaxial polydactyly - a new syndrome? Part I: clinical, causal and pathogenetic considerations. Am F Med Genet 1980;7: 47-74.

19 Iafolla K, Fratkin JD, Spiegel PK, Cohen MM Jr, Graham JM. Case report and delineation of the congenital hypothalamic hamartoblastoma syndrome (Pallister-Hall syndrome). $A m \mathcal{F}$ Med Genet 1989;33:489-99.

20 Verloes A, Gillerot Y, Donnay M, Langhendries JP, Fryns JP, Koulischer L. Syndromatic hypothalamic hamartoblastoma (Marcuse-Hall-Pallister syndrome). Another case and critical review of the literature. Am 7 Med Genet (submitted).

21 Anyane-Yeboa K, Collins M, Kupsky W, Malman J, Malin J, Yeh M. Hydrolethalus (Salonen-Herva-Norio) syndrome: further clinicopathological delineation. Am $\mathcal{F}$ Med Genet 1987; 26:899-907.

22 Varadi V, Szabo L, Papp Z. Syndrome of polydactyly, cleft lip/palate or lingual lump, and psychomotor retardation in endogamic gypsies. F Med Genet 1980;17:119-22.

23 Grote W, Rehder H, Weisner D, Wiedemann HR. Prenatal diagnosis of a probable hereditary syndrome with holoprosencephaly, hydrocephaly, octodactyly and cardiac malformations. Eur f Pediatr 1984;143:155-7.

24 Burk U. Genetic counselling in holoprosencephaly. Helv Paediatr Acta 1982;37:231-7.

25 Moerman P, Fryns JP, van der Steen K, Kleczkowska A, Lauweryns J. The pathology of trisomy 13 syndrome. Hum Genet 1988;80:349-56.

26 Pallister PD, Hecht F, Herrmann J. Three additional cases of the congenital hypothalamic "hamartoblastoma" (Pallister-Hall) syndrome. Am f Med Genet 1989;33:500-1.

27 Cohen MM. Perspectives on holoprosencephaly. Part I. Epidemiology, genetics, and syndromology. Teratology 1989;40: 211-35.

28 Cohen MM. Perspectives on holoprosencephaly. Part III. Spectra, distinctions, continuities, and discontinuities. $A m \mathcal{F}$ Med Genet 1989;34:271-88.

29 Enke M. Clinical, cytogenetic, and molecular approaches to the genetic heterogeneity of holoprosencephaly. Am F Med Genet 1989;34:237-45.

30 Johnson VP. Holoprosencephaly: a developmental field defect. Am F Med Genet 1989;34:258-64.

31 Demyer $W$. Holoprosencephaly (cyclopia-arhinencephaly). In: Myrianthopoulos NC, ed. Handbook of clinical neurology. Vol 6. Malformations. Amsterdam: Elsevier, 1987:225-44.

32 Probst FP. The prosencephalies. Morphology, neurological appearances and differential diagnosis. Berlin: Springer-Verlag, 1976.

33 Roach E, DeMyer W, Conneally PM, Palmer C, Merrit AD. Holoprosencephaly. Birth data, genetic and demographic analysis of 30 families. Birth Defects 1975;11:294-313.

34 Warkany J, Lemire RJ, Cohen MM. Mental retardation and congenital malformations of the central nervous system. Chicago: Year Book Medical Publishers, 1980:176-90. 